\title{
THE OCULOCARDIAC REFLEX AND SINO-ATRIAL ARREST*
}

\author{
R. Brian SmTth, $\nmid$ M.B., B.S., Harlan Dovglas, M.d., \\ and Jarosla w Petruscak, M.D.
}

The oculocardic neflex was FIrst DESCribed independently by Bemard Aschner ${ }^{1}$ and Giuseppe Dagnini ${ }^{2}$ in 1908 . Traction on the extra-ocular muscles and pressure on the eyeball can evoke this reflex, manifested by bradycardia and cardiac arrhythmias. The afferent pathway consists of fibers which run through the short ciliary nerves to the ciliary ganglion, and then with the ophthalmic division of the trigeminal nerve to the Gasserian ganglion. Afferent fibers also pass in the long ciliary nerve and then again in the opthalmic division of the trigeminal nerve to the Gasserian ganglion. From this ganglion, both groups of afferent fibers terminate in the main sensory nucleus of the trigeminal nerve in the fourth ventricle. The efferent limb is the vagus nerve. Thus, the reflex is the trigemino-vagal.

A number of cardiac arrests have been associated with the oculocardiac reflex. $K_{i r s c h}{ }^{3}$ reported a rate of one per 3,500 anaesthetics for operations on the eye. Knoblock and Lorenz ${ }^{4}$ found that out of 300,000 patients sixty died while undergoing operations for strabismus, and Bietti reported one cardiac arrest in 2,200 cases of general annesthesia for strabismus operations.

Numerous methods of blocking the afferent or efferent pathways have been tried with varying degrees of success. The following two case reports illustrate some of the difficulties that may be encountered.

\section{Patient 1}

A 53-year-old white female was admittcd to the Eye and Ear Hospital for surgical treatment of retinal detachment of the left eye. The past medical history was uneventful and the retinal detachment was the only abnormal physical finding. Electrocardiogram and roentgenogram of the chest were normal. Atropine 1 per cent eye drops were used daily.

Three operations were performed on the left eye for treatment of the retinal detachment.

First Operation: Premedication consisted of atropine $0.6 \mathrm{mg}$, pentobarbital $175 \mathrm{mg}$ and hydroxyzine $100 \mathrm{mg}$ intramuscularly 45 minutes before induction of anaesthesia. This was accomplished with $300 \mathrm{mg}$ of 2 per cent thiopentone. Following $60 \mathrm{mg}$ of succinylcholine intravenously, the larynx was sprayed with $100 \mathrm{mg}$ of lidocaine and the trachea was then intubated. Anaesthesia was maintained with nitrous oxide and halothane. The conjunctiva was opened and a bridle suture was placed under the superior and lateral recti muscles. No change was noted in the

- From the Department of Anesthesiology, Eye and Ear Hospital, University of Pittsburgh School of Medicine, Pittsburgh, Pennsylvania 15213.

fAddress correspondence to: R. Brian Smith, M. B., B.S. 
heart rate, which remained at 80 beats per minute. Cryotherapy on the retira and choroid proceeded uneventfully.

Second Operation: This was carried out 12 days after the previous operation. Premedication was identical but was given 70 minutes before induction. Anaesthesia was induced with $210 \mathrm{mg}$ of 2 per cent thiopentone followed by $50 \mathrm{mg}$ of succinylcholine. The larynx was sprayed again with $100 \mathrm{mg}$ of lidocaine and the trachea was intubated. Anaesthesia was maintained as previously with nitrous oxide and halothane. As the inferior rectus muscle was grasped in order to place a bridle suture, the pulse disappeared ahd this was associated with loss of electrocardiographic activity on the cardioscope. Approximately five seconds after the onset of sinus arrest and following cessation of muscle traction, sinus rhythm and a palpable pulse at 80 beats per minute returned spontaneously. Atropine $0.5 \mathrm{mg}$ was given intravenously and the heart rate increased to 100 beats per minute. The operation was terminated and the patient's recovery from anaesthesia was uneventful.

Third Operation: Four days after the previous operation the same medication was again given, this time 65 minutes before induction, but general anaesthesia was preceded by a retrobulbar block with $40 \mathrm{mg}$ mepivacaine 2 per cent. Induction was with $400 \mathrm{mg}$ thiopentone followed by $60 \mathrm{mg}$ succinylcholine. The larynx was sprayed as before with $100 \mathrm{mg}$ lidocaine and the trachea was then intubated. Anaesthesia was maintained again with nitrous oxide and halothane. Bridle sutures were placed under the superior, medial, and inferior recti muscles. On muscle traction, sinus arrest occurred.

Muscle traction was stopped at the onset of sinus arrest and the return to normal sinus rhythm was spontaneous. Atropine $0.4 \mathrm{mg}$ was given intravenously and this increased the heart rate to 100 beats per minute. Subsequently, traction on the eye muscles elicited no change in the heart rate. Cryotherapy was completed uneventfully and the recovery from anaesthesia was uncomplicated.

\section{Patient 2}

A 60-year-old white male was admitted to the Eye and Ear Hospital for a second cataract extraction. The first operation had been performed successfully six months previously under local anaesthesia. The past medical history was uneventful, and physical examination and laboratory findings were normal. Premedication consisted of hydroxyzine $50 \mathrm{mg}$ and pentobarbitone $90 \mathrm{mg}$ given 45 minutes before the operation. Atropine was not given because the operation was scheduled to be done under local anzesthesia, but because of the patient's severe apprehension, the anaesthesia was changed to general at the last moment. Atropine $0.4 \mathrm{mg}$ was administered intravenously prior to induction of anaesthesia. This was accomplished with thiopentone $300 \mathrm{mg}$ followed by $80 \mathrm{mg}$ succinylcholine. The larynx was sprayed with $100 \mathrm{mg}$ lidocaine 2 per cent and the trachea was intubated. Anaesthesia was maintained with nitrous oxide and halothane. Approximately ten minutes after the administration of atropine, a retrobulbar injection of $40 \mathrm{mg}$ mepivacaine 2 per cent was made. On retraction of the globe by forceps on the inferior rectus muscle, sinus arrest of 5 seconds duration occurred. Sinus rhythm returned spontaneously after cessation of traction on the muscle. An additional 
$0.4 \mathrm{mg}$ atropine was given intravenously and no change in heart rate occurred on subsequent muscle traction. The operation was completed without further complication and recovery was uneventful.

\section{Discussion}

Cardiac arrhythmia may occur following the administration of succinylcholine. Bradycardia was found in 83 per cent of patients after a repeated dose of succinylcholine by Lupprian and Churchill-Davidson, ${ }^{6}$ and in 80 per cent of patients by Mathias and Evans-Prosser. ${ }^{7}$ In the cases here reported, the patients had recovered from the intubation dose of succinylcholine before the start of the operation. Repeated doses of succinylcholine were not given.

In 1958, Bosomworth et al. ${ }^{8}$ studied the effects of atropine in blocking the oculocardiac reflex. They found changes in cardiac rhythm following traction on the medial rectus muscle in 86 per cent of their patients. Traction on the external recti produced changes only in 40 per cent of the patients. The majority of cases showed a decrease in pulse rate of only between 10 and 50 per cent. Additional disturbances included nodal rhythm, atrioventricular block, and bigemini. All the patients had received between 0.1-0.4 $\mathrm{mg}$ of atropine subcutanequsly 30 to 120 minutes before the operation. The intravenous administration of half the premedicating dose of atropine given just before the operation reduced the incidence of bradycardia to about six per cent. In our second patient, $0.4 \mathrm{mg}$ atropine, given intravenously approximately ten minutes before the retrobulbar injection, failed to prevent sino-atrial arrest. This may have been related to the dose of atropine administered. According to Artusio and Mazzia," atropine can prevent reflex sinus arrest, but the dose required ranged between one and two milligrams. Doses less than $0.5 \mathrm{mg}$ given intravenously less than 45 minutes preoperatively can even produce initial bradycardia. Doses larger than $0.5 \mathrm{mg}$ intravenously produce tachycardia with the heart rate increasing by 20 beats per minute. ${ }^{10,11}$ The timing of the administration of atropine may also be important. According to Collins ${ }^{11}$ and Gaviatki, ${ }^{12}$ the peak action of atropine administered intramuscularly is 30 to 45 minutes. After 60 minutes, the vagolytic effect of the atropine on the heart is negligible, ${ }^{0,11,12}$ The dose of atropine required to produce complete vagal blackade in an adult is $2-3 \mathrm{mg}$.

Retrobulbar block has been shown by Mendleblatt ${ }^{14}$ and Berler ${ }^{15}$ to offer considerable protection, but the latter felt that the risk of complication exceeded the risk from arrhythmias. In some hands, retrobulbar block has been ineffective. ${ }^{8}$ In one study, a retrobulbar block itself elicited the reflex in 44 per cent of patients. ${ }^{18}$ In our second patient, sinoatrial arrest occurred despite the retrobulbar injection.

In a study of 191 patients scheduled for surgical correction of strabismus at Columbia Presbyterian Medical Center, New York City, the incidence of oculocardiac reflex was 72 per cent; a retrobulbar block decreased this to 35 per cent, while intravenous or intramuscular atropine decreased it to 30 per cent. However, following atropine the arrhythmias seen were more severe and prolonged than those in the untreated patients. Consequently, both atropine and retrobulbar block were abandoned. Presently, at Columbia Presbyterian Medical Center, the electro- 
cardiogram is monitored and if an arrhythmia appears and persists, the surgeon stops the manipulation temporarily. After six years and more than 2,000 patients, this method is still in use. ${ }^{17}$ With repeated handling of the extrinsic muscles of the eye, bradycardia is less likely to occur, presumably because of fatigue of the oculocardiac reflex at the level of the cardio-inhibitory centre. ${ }^{18}$

In 1966, Pontinen ${ }^{16}$ studied the incidence of a positive oculocardiac reflex in 818 patients undergoing operations on the eye. Croups of patients received either local anaesthesia or halothane or neuroleptanaesthesia. The incidence of a positive oculocardiac reflex was high in patients who did not receive intravenous atropine and also in patients with spontaneous respiration. The incidence was low in patients whose respirations were controlled and in those who had intravenous atropine or gallamine.

Deacock and Oxer ${ }^{19}$ compared three groups of patients, all of whom had been anaesthetized with a sequence of thiopentone for induction, succinylcholine for tracheal intubation and halothane, nitrous oxide for maintenance. The first group received no additional muscle relaxants. The second group received gallamine $0.9 \mathrm{mg} / \mathrm{kg}$. The third group received d-tubocurarine $0.18 \mathrm{mg} / \mathrm{kg}$. The first group showed a fall in mean pulse rate from 81 to 54 per minute on traction of the medial rectus muscle. The second group showed a fall from 113 to 101 per minute, and the third group a fall from 84 to 57 per minute.

The mechanism of the increased heart rate caused by gallamine is twofold. Firstly, it has a vagolytic ${ }^{20}$ effect similar to atropine and secondly, it has been shown to have a positive chronotropic effect which can be blocked by propranolol. We were unable to find any references to serious arrhythrnia occurring in patients undergoing eye operations following the administration of gallamine.

In conclusion, neither the administration of intramuscular atropine with the preoperative medication nor a prophylactic retrobulbar block appears to be of value in preventing the oculocardiac reflex. On the other hand, intravenous atropine given in adequate doses within 30 minutes of operation offers considerable protection. Gallanine may also be of value in preventing the oculocardiac reflex.

\section{Résumé}

Nous rapportons deux arrêts sino-auriculaires reliés an réflexe oculocardiaque. Un de ces malades a été opéré trois fois sons anesthésie générale pour décollement de la rétine. Au cours de deux de ces opérations, alors que des techniques différentes d'anesthésie étaient employées, il l a eu arrèt sinusal. Le deuxième malade était opéré pour ablation de cataracte. L'arrêt sinusal est survenu dix minutes après l'administration d'atropine par voie endo-veineuse. Nous discutons des méthodes de prévention du réflexe oculocardiaque.

En conclusion, ni l'administration d'atropine par voie intramusculaire en prémédication, ni le blocage prophylactique rétrobulbaire ne semble de quelque valeur dans la prévention du réflexe oculocardiaque. L'atropine à des doses adéquates donnée par voie endoveineuse au cours des trente minutes qui précèdent la chirurgie procure une protection considérable. La gallamine peut également constituer une protection valable contre le réflexe oculocardiaque. 


\section{REFERENCES}

1. Aschner, B. Ueber einen bisher noch nicht beschriebenen Reflex von Auge auf Krieslauf und Atmung. Verschwinden des Radialpulses bei Druck auf das Auge. Wien. Klin. Wschr. 21: 1529 (1908).

2. DAGNINI, $G$. Intorno ad un riflesso provocato in alcuni emiplegici collo stimolo della cornea e colla pressione sul bulbo oculare. Bull. Sci. Med. 8: 380 (1908).

3. KIrscr, R.E.; SAMEt, P.; Kugez, V.; \& AxELrod, S. Electrocardiographic Changes During Ocular Surgery and their Prevention by Retrobulbar Injection. A.M.A. Arch. Ophth., 58 : $348(1957)$.

4. Knonlock, R. \& Lonfinz, A. Uber ernste Komplikationen nach Schieloperationer. Klin. Mbl. Augenheilk., 141: 348 (1962).

5. BIEтri, G.B. Problems of Anesthesia in Strabismus Surgery. International Ophthalmology Clinics, 6: 727 (1966)

6. Lupprian, K.G. and Churchill-Davidson, H.C. Effect of Suxamethonium on Cardiac Rhythm. Brit. Med. J., 2: 1774 (1960).

7. Mathias, J.A. \& Evans-Prosser, C.D.G. An Investigation into the site of action of Suxamethonium on Cardiac Rhythm. Progress in Anesthesiology, Excerpta Medica Foundation (Amsterdam) I153 (1970).

8. Bosomwonth, P.P.; ZIEGLER, C.H.; \& JAconx, J. The Octuo-Cardiac Reflex in Eye Muscle Surgery. Anesthesiology, 19: 7 (1958).

9. Antusio, J.F., Jn., \& MazziA, V.D.B. Practical Anesthesiology. St. Louis, C.V. Mosby Company, 1962, p. 70 and 91 .

10. Goonman, L.D. \& Grlman, A. The Pharmacological Basis of Therapeutics, 4th ed. New York, The MacMillan Company, 1970, Chapter 25, p. 530.

11. Concins, V.J. Principles of Anesthesiology. Philadelphia, Lea and Febiger Company, 1966, P. 1001.

12. Gaviatki, A. \& SMrth, A. Use of Atropine in Pediatric Anesthèsia. International Anesthesiology Clinics, $1: 109$ ( I962).

13. Drus., $U$, Pharmacology in Medicine. New York, McGraw-Hill Book Company, Inc., 1954, Chapter 27, p. 3.

14. Mendelalatt, F.; Krasch, R.E.; \& Lembeng, L. A Study Comparing Methods of Preventing the Oculo-Cardiac Reflex. Am. J. Ophth., 53: 506 (1962)

15. BenLef, D. The Oculocardiac Reflex. Am. J. Ophth., 56: 954 (1963).

16. Pontinen, P.j. The Importance of the Oculocatdiac Reflex During Ocular Surgery. Acta Ophth. Suppl., 86 (1966).

17. KATz, R.L. \& BIGger, J.T. Cardiac Arrhythmias During Anesthesia and Operation. Anesthesiology, 33: $193(1970)$.

18. Moonie, G.T.; ReEs, D.I; \& Elton, D. The Oculocardiac Relex During Strabismus Surgery. Canad. Anaesth. Soc. J., 11: 621 (1964).

19. Deacock, A.R. DE C. OXË, H.F. The Prevention of Reflex Bradycardia During Ophthalmic Surgery. Brit. J. Anaesth., 34; 451 (1962).

20. Rrkera, W.F. \& Wescoe, W.C. The Fharmacology of Flaxedil with Observations on Certain Analogs. Ann, N.Y. Acad, Sci., 54 : 373 ( 1951 ).

21. Brown, B.R. \& CRout, J.R. The Sympathomimetic Effect of Gallamine on the Heart. Anesthesiology, 29:179 (1968). 